\title{
Sufi Practices for the Health of Body and Soul
}

\author{
Riaz Uddin Riaz, MD \\ Bluefield, West Virginia
}

\begin{abstract}
This paper covers the historic perspective of Suff traditions and outlines the various practices this tradition has given us, some of which have been adoped by western plyysicians and practionioners. The practice of retreat and "Dhikr" will be dealt with in detail with information as to the benclits for the body and soul.
\end{abstract}

Key words: Sufi, ibn Sinā, neditation

E.W. Lane's Arabic English Lexicon defines the word "Șufi" as a posiclassical word meaning one who secks to raise himself to a high degree of spiritual excellence by contemplalion of divine things.

The most commonly accepted explanation of the word's origin is dhat it is derived from "suf," (wool) and those who wear woolen attire with humbleness. Another explanation is that sufis are those who are first in line, derived from the rool "salf" (row).

'Ahl-ul-sajă were in Uhe Prophet Mulianmad's mosque day and night dedicaling thenselves to learning from him, abandoning every oller worldly need. The number of 'ahlul-șāẩ' varied al any given lime. Among them were 'Abü Hurayrah, Bilāil, and Salmān al-Färisī. Hence, sufis are those who are like'allı-ul-șifä.'

Another artuactive derivation of suf is from the word "safâ," meaning purity. Dr. Mir Valiuddin said in "The Qur'antic Sufism"' that "some say the sufis were only named sufis because of purity of their hearts and the cleanliness of their acıs." Bashir ibr al-Härith said, "the sufn is he whose licarl is sincere lowards God." Junid al-Baglıdadi wrote. "Sufism is not achieved by nuch praying and fasting but it is security of heart and generosily of soul. The whole of the body is reformed and all the actions improved by purity and

Reprimt Requesis: Riaz Uddin Riaz, MD

323 Ramsey Street

Bluefield, WV 24701 sincerity of heart. The unveiling of divine gnosis is entirely dependent on inner purity."

Shaik-al-Islam Zakariyyā Anșärí summarizes lhaı "sufism teaches how to purify one's self, improve one's morals, and build up one's inner and outer life in order to attain perpetual bliss. Its subject matter is the purification of the soul and its end or aim is the attainment of eternal felicity and blessedness."1

According to Imam Qushayri, the word Sui became popular in the end of second century Hijri (about llie loth century of C.E.).'

The question arises as to what term was used for people who had the qualitics of sufis before this lime? During the Prophet's time and after, they had the urile of "sallaba" or companions. Then came the "Tà bi "in" (followers) and then Täbi' al-Tabi 'in (followers of the followers). They were models for sufis. They all had their special titles.

Mystics of Islam did not confine themselves with only the search of cosmic reality. They also took deep interest in the natural sciences. Sufi practices gave them the freedors of thought and keen intellecl, which resulted in the golden age of scientific inquiry and development. Some of them werc prolific writers.

Original thinking in various aspects of the medical field, including psychology, was part of this heritage. The whole world, even today, celcbrates ibn Sinà's contributions.

Ibn Miskäwyih and Nàssinuddin al-Tusi gave us the understanding of evolution and human devclopment, which is 
strikingly modern. About seven centuries ago, Jaläluddin al-Rumi was inspired to say the following about evolution (as Rober Bly, the contemporary American poet, renders al-Runi's thoughts). ${ }^{2}$

1 lived for thousands and thousands of years as a mineral.

And then I died and became a plant.

And then I lived for llousands and thousands of years as a plant.

And lhen I died and became an animal.

And I lived for thousands and thousands of years as an animal

And then I died and became a human being. Tell me, what have I ever lost by dying?

Keen interest in original writings of suft masters of old is noted in western publications. Some such works are translated for the first lime in English, French, and German from Arabic and Persian.

Islanuic spirituality is very appealing to the modern mind. Demand for more underslanding and opportunity to experience Sufi praclices is rising. Pcople are searching for the straight path. Several organizations representing old traditional "Turuq" or orders (Suli traditions) have been established in Europe and the Americas. Spontaneous new groups are also in exislence. Unfortunately. sucl groups do not have the background in the "Shari"ah" (juris prudence) based on the Qur'än and "Sunnali" (Prophel Muhammad's sayings and iraditions). It is up to pcople who are blessed enough to have such fundamental knowlcoge lo lake interest in our sult heritage and to take the lcad.

It was lmam al-Ghazaji who was influential in reconciliation between the shari'ah law and the Sufi path. At the height of his career as an eminent theologian and religious authority, al-Ghazäli left everything in search for the peace of heart. He travcled for several years in Syria, Jerusalem, and possibly Egypl acquiring sufi knowledge. After his enlightenmen1, he wrote his famous work "Ihyā' 'Ulün alDin," (the Revival of Religious Sciences). He clarified the issues of both al-shari"all and the "Tarigah" (singular of TuruQ). Further such clarificalion and reconciliation occured by Uhe teachings of 'Abd-ul-Qädir al-Jiläni.

Muluanunad Ajmal in his aricle "Sufi Science of the Soul." appearing in the Islamic Spirituality Foundations, stales "the hean is the abode of divine light. Divine knowledge can be altained lluough its activity. God has called if His own abode." Propliẹ Mulnammad [PBUH] has said that the heart is the house of God. He also said:

"Truly in the body there is a lunip of flesh which if it be heallhy. all the body is healthy; if it be discased the whole body is diseased, truly il is the heart."

In Islamic Iradilions, personality struclure depends on these clements:
1. "Al-Rüh" - (the spirit)
2. "Al-Qalb" - (the beart)
3. "Al-Nafs" - (the soul)

The stages of the evolution of the nafs evolves are:

1. "Al-Nafs al-Hayawaniyyah": the animal soul, obedient to natural desires and instincts.

2. "A]-NaIs al-'Ammarah": the passionale, egoistic soul.

3. "Al-Nafs al-Lawnāmah": the soul, which is aware of its own imperfections.

4. "Al-Nafs al-Mutma'innah": the soul at peace, the soul reintegrated in the spirit and at rest in certitude. (Islamic Spirituality Foundations)

There is a strugglc between the rill (spirit) and nafs (sow) to overcome the heart. If the nafs wins, the heart is veiled or diseased. Most hearts can never lift the veil of mundane passions and desires that cover the heart. It is described in sufi traditions as rust. This rust can be removed only by persistent invocation, or Dhikr. The Qur'ān states:

"God has sealed off their hearts and their hearing while over their sight there hangs a covering. They will have severe torment. Some people say we believe in Allāh and the last day while they are not believers. They would like to deceive God and those who believe, while they merely outwit themselves and do not notice it. In their hears is a disease and Allāh increases their disease. Grievous is the penalty they incur because they are false to themselves."

Suruggle with the nafs has been called "al-Jihà al-Akbar" (the greatest struggle) by the Prophet. In another Hadith, the Prophat [PBUH] was quoted to have said:

"You have come to me to ask about rightcousness?" The questioner said, "Yes." The Prophel answered, "Consult your heart." Righteousness is that about which the soul feels tranquil and the heart feels tranquil, and wrong doing is that which wavers in the soul and moves to and fro in the breast even though pcople again and again have given you their legal opinion [in its favor]."'

Dr. Mohammad Shafii, in his book, "Freedom From The Self," gives the various stages through which such a struggle occurs:
1. "Al-Tawbah": Repentance
2. "Al-Wara": Abstinence
3. "Al-Zuhd" : Renunciation
4. "Al-Faqr": Poverty
5. "Al-Sabr": Patience
6. "Al-Tawakkul": Trusı in God
7. "Al-Ridăh": Contenument

At the level of contentment, he states, we achieve "alNafs al-șăfiyah wal-Kämilah" (the pure and the accontplished/complete soul).

'Anas [RAA] reported a Hadith about tawba (repentence). Prophet Muhammad [PBUH] said:

"Allahh the Almighty has said: ' $O$ son of Adam, so long as you call upon Me and ask of Me, I shall forgive you for what you have done, and I slatl not 
mind. O son of Adam, were your sins to reach the clouds of the sky and were you then to ask forgiveness of Me, I would forgive you. O son of Adam, were you to comc to Me with sins nearly as great as the earth and were you then to face Me, ascribing no partner to Me. I would bring you forgiveness nearly as great as your sins."'A

On renunciation, a Hadith is quoted in Ibn Mājah:

"A man came to the Prophet JPBUH] and said: 'O Messenger of Allāh, direct me to an act which, if I do it, | will cause] Allill to love me and people to love me.' He said: 'Renounce the world and Alläh will love you, and renounce what people possess and people will love you."

Harvard researcher Herbert Benson, MD in his books "The Relaxation Response" and "Bcyond the Relaxation Response," came to the conclusion after years of research on medieation that an additional faith factor is needed to harness the healing power of a Muslim's personal beliefs. He is only confirming what sufi masters have taught for oenturics. Diklu is the sufi practice of meditation. It is a practice supported by the Qur'än and Sunnah. Allāh says:

"Remember nic and I will remember you."

"Those who believe, and whose hearts find their rest in the remembrance of God - for verily, in the remembrance of God |men's| hearts do find their rest."

Hadith on the authorily of 'Abu' Hurayrah [RAA] narrated that the Prophet [PBUH] said:

"Alāh the Almighty says:

'I am as my servant thinks I am. I am with him when be makes mention of Me. If lic makes mention of Me to himself, I make mention of him to Myself; and if he makes mention of Me in an assembly, 1 make mention of him in an assembly. And if he draws near to Me a hand's span, I draw near lo him a fathom's length. And if he comes to me svalking, I go to him at specd."
Al-Ghāzāli in his work. "al-Mạșad al-"Asnā fï sharḥ Asmā' Allāh al-Husnā," for reciling the most beautiful names of Alläh and offers counsel on how an individual can share the divine attributes and make himself more pleasing to God. And hence, to his fellow beings.

Also available now is al-Ghāzāli's "Kitāb al-adlukär wa'l du 'ä' (Invocations and Supplications)" in English translalion, which enumerates the benefits of Dikhr. ${ }^{10}$

The power of Dikhr, in addition to elevating the sout or the practitioner, helps in healing the body, reduces anxiety and depression, helps relieve symptoms related to anxiety, such as nausea, voniling, diarrhea, and constipation. It also reduces the pain of headache, backache, and angina. It reduces blood pressure, corrects insomnia, enhances creativity and can help in treatment of cancer.

Other sufi practices to relieve tension and anxiely are storytelling, poetry, and dream interpretation

\section{References}

1. Valiuddin, M. The Qur'ānic Sufism. 1991. Labore, Pakistan: Ashraf Printing Press.

2. Pocms of Rumi. Rober Bly and Coleman Barts Audio Literalure: Berkeley, California.

3. The Glorious Qur'ān. Chapter 2, verse 7-10.

4. Ibrahim, Ezzedin, Johnson-Davies (translators): A!Nawawì's. Forty 'Ahädith. 1985. Safat, Kuwait: Saliābalı Islamic Press.

5. Shafii M. Freedom from the Self. 1988. New York: Human Sciences Press.

6. Benson H. The Relaxation Response. 1976. Avon Publishers.

7. Benson H. Beyond the Relaxation Response. 1984. New York: Berkley Books.

8. The Glorious Qur'ān. Chapter 2, verse 152.

9. The Glorious Qur'ān. Chapter 13, verse 20

10. Al-Ghàzäli. Invocations and Supplications. Translated by K. Nakamura. 1990. UK: The Islamic 'Texts Society. 